\title{
Determinants of Social Entrepreneurship in Ukraine
}

\author{
Nataliia Gavkalova ${ }^{1 *}$, Oleg Amosov ${ }^{2}$, Alona Zolenko ${ }^{3}$ and Iryna Sierova ${ }^{4}$ \\ 1"Karazin Business School” V.N. Karazin Kharkiv National University \\ Management and Administration Department. Kharkiv, Myronosytska str. 1 \\ ${ }^{2}$ Kharkiv Regional Institute of Public Administration of the National Academy of Public \\ Administration (Kharkiv) \\ Public Theory and Finances Department, Kharkiv, Moskovsky av. 75 \\ ${ }^{3}$ Simon Kuznets Kharkiv National University of Economics (Kharkiv) \\ Public Administration and Regional Economy Department, Kharkiv, Nauky av. 9-A \\ ${ }^{4}$ Simon Kuznets Kharkiv National University of Economics (Kharkiv) \\ Economic Theory, Statistics and Forecasting Department, Kharkiv, Nauky av. 9-A
}

\begin{abstract}
The high importance of social entrepreneurship for the development of national and regional economies is widely recognized. This article contributes to the emerging theoretical discourse of social entrepreneurship by explicating the representatives of different schools. Social entrepreneurship occupies a third sector between the private sector of the economy and the non-profit sector as it aims to solve social problems. Social entrepreneurship functions as an organization that selfsustains at the expense of the innovative organization of its core business. The article suggests holistic approaches to entrepreneurship research based on entrepreneur-associated factors, characteristics of the political and legal environment. These determinants can have direct or indirect influences on entrepreneurial processes mandatory for the development of social entrepreneurship.

To determine the strengths and weaknesses of the development of social entrepreneurship in Ukraine, as well as its opportunities and threats, the SWOT analysis was carried out. The actions required to improve the current state of social entrepreneurship were justified. The detection of threats and opportunities has made it possible to identify priorities for the development of social entrepreneurship in Ukraine, taking into account existing risks.
\end{abstract}

\section{Introduction}

The transition of certain functions from the government to business plays a crucial role in the development of modern society under the current economic conditions and intense competition. This phenomenon could be due to a number of factors. The society in economically developed countries has begun to impose higher requirements for corporate social responsibility and many national and regional policy initiatives aim to promote

*Corresponding author: ngavl@ukr.net 
business start-ups and foster their growth as newly-founded firms contribute to the dynamism of the economy [1] whereas business representatives are getting aware of the need for a wider range of social functions and determinants. The combination of these factors has contributed to the creation of a social enterprise, that is, third sector organizations whose activities are aimed at solving or mitigating the problems of society.

\section{Literature Review}

Research on social entrepreneurship as a phenomenon has evolved and has been refined over the past few decades. However, before defining "social entrepreneurship|", it is crucial to determine the nature of the categories "entrepreneurship" and "entrepreneur" as well as its features and functions:

entrepreneurship is an interdisciplinary category and serves as an object of research in economics, management, sociology, psychology, and other socio-humanities; entrepreneurship is an independent factor in production;

entrepreneurship has recently become a type of professional activity;

entrepreneurial skills are an integral part of innovation development. J. Schumpeter indicates that an individual can be referred to as an entrepreneur only if he or she utilizes a new mix of resources [2];

an entrepreneur is an innovator who organizes and coordinates economic resources.

Modern society faces a number of unsettled issues in the non-profit social sector. Third sector organizations in the form of public-private partnership and social entrepreneurship exercise socially oriented activities and launch various projects to meet the needs of the society.

In the study which set out to classify the third sector organizations activities, four main schools of thought have been distinguished - the English one, the European one, the socio-innovative one and the socio-entrepreneurial one. The representatives of the social innovation school of thought (S. Elward, J. Mayr, I. Marty, J. Thompson) consider social entrepreneurship as an activity of individuals who are responsive to social needs by innovative methods. The subject of the study of representatives of the socio-entrepreneurial school (R. Anderson, R. Dart, R. McDonald) is non-profit organizations that serve the nonprofit social sector and receive additional income therewith. Within the framework of this school, scientists are engaged in the search for new ways of funding non-profit organizations, as well as implementing effective management methods in the activities of socially-oriented enterprises. The representatives of the European school (I. Vidal, R. Speer, U. Stefan, L. Ulaner), determine the purpose of socially oriented activities as the satisfaction of the society's interests and emphasize the impossibility of the entrepreneurship existence without the strong state support. According to the approach of the English school of thought of social entrepreneurship (L. Darby, S. Dixon, A. Clifford, K. Linging, D. Turner, H. Jenkins), solving social problems should rely entirely on business, with the proceeds being directed, first of all, for the satisfaction of social needs.

Factors that both enable and constrain innovation processes to meet the financial, social, cultural, and political expectations of stakeholders of social entrepreneurship ventures have been explored in several studies, such as additional sources of resistance that stem from its alternative, or multiple, institutional logics; greater dependence of social entrepreneurship on stakeholder support, as well as the measurement of social entrepreneurship success across the dual objectives of social impact and financial selfsufficiency; legitimacy of social entrepreneurship as a form of organizing and method of social change [3]. 
Although social entrepreneurship is not an entirely new phenomenon, there is very little scientific understanding of the mechanisms by which third sector organizations function and develop. However, as the report on the large-scale study of social enterprises in Europe, "A map of social enterprises and their eco-systems in Europe" points out, much of the research up to now has been unsatisfactory [4]. The main purpose of this mini research is to develop an understanding of the social entrepreneurship and determinants and analyze the dynamics of the social entrepreneurship development in Ukraine.

Social entrepreneurship is a new way of social and economic activity, which combines the social purpose of the organization with entrepreneurial innovation and a wellbalanced structure for self-sustainability. According to K. Alter, the functioning of social entrepreneurship is based on social enterprises that are formed to address a particular social problem or problems and operate on the basis of innovation, financial discipline and business behavior adopted in the private sector [4, p. 12].

If we focus on the economic consequences of this phenomenon, social entrepreneurship increases overall economic efficiency, since it introduces into the economic turnover resources that were previously not used in this quality. This, first and foremost, concerns unused material and human resources - waste products, socially formed groups, solidarity and trust of people when they are united by a common goal.

Data from several foreign sources concerning the formation and development of a social enterprise have identified that the focus of social projects has changed significantly. Traditionally, many social projects were aimed at working with people with disabilities, nowadays more and more newly-formed businesses deal with issues of emigrants, national minorities, and ecology. These data confirm the state's interest in the formation of social institutions, which will contribute to the more effective implementation of the state policy.

\section{Results}

It is apparent that social entrepreneurship is a relatively new concept that combines many different determinants of the third organizations' activities. The primary mission of social entrepreneurship is the creation of social value and the pursuit of social change. Therefore, any forces that limit or constrain the social innovation processes are perceived by researchers as negative because they reduce the positive social change that could potentially be achieved [5]. Consequently, social entrepreneurship is an activity of enterprises that uses innovations and functions to solve any social problem or create benefits for society, rather than maximizing profits for the enterprise owners.

Conceptual provision for the formation and development of social entrepreneurship is presented in Fig. 1

The main task of social enterprises is to create positive changes that can be reflected in terms of measurable indicators. Social impact measurements serve as a tool for assessing, presenting, improving the activities of a social enterprise and attracting clients and investors.

Taken together, the following conclusions can be drawn from the present study, the main determinants of social entrepreneurship are the following factors, such as

favorable political climate;

adequate legal environment;

innovation and scientific infrastructure;

dynamic and active socio-cultural environment.

It should be emphasized that the political and legal environment provides opportunities for social entrepreneurship formation, while the socio-cultural environment creates favorable conditions for its existence, and government institutions stimulate social entrepreneurship growth and promote its further development. 
The findings of this study suggest that social entrepreneurship can be characterized by the following features: the predominance of a social mission over a commercial component; the pursuit of long-term changes in the social sphere (its reformation); competitiveness, self-sustainability and cost-effectiveness; high responsibility of a social entrepreneur for the results of his/her activity; the use of innovations to solve social problems. Regarding the formation and development of social entrepreneurship in Ukraine, it should be recognized that the relevance of this study is confirmed by the lack of both legislative and methodological basis.

Prerequisites for the creation of social enterprises (crisis economic processes, military operations, limited budget resources for financing social sphere, a significant amount of public debt)

Purpose (use of innovative approaches in the social non-profit sector and
achievement of the social effect at the expense of distribution and use of profit for the
fulfillment of a social mission)

The basic principles (democratic decision-making style, common and equal ownership of all members of the enterprise, the mission of social entrepreneurship is aimed at creating social wealth, not profit)

Sources of financing (own commercial activity, grants, sponsorship, and charitable contributions, budget funds, loans from various financial institutions)
Areas of activity (enterprises engaged in labor, medical and social rehabilitation of people with disabilities; educational services; production of agricultural products; food industry; repairs, etc.)

Government instruments of influence (interest-free and low-interest loans, preferential taxation, subsidies from the budget)

Indicators of the efficiency of social enterprises (indicators of economic efficiency: reduction of budget expenditures, an increase of budget revenues, alternative sources of financing of social non- profit sector, indicators of social efficiency: employment of the population, support of socially vulnerable groups of population, professional rehabilitation and adaptation to public life)

Fig. 1. Conceptual provision for the formation and development of social entrepreneurship.

Thus, according to most researchers [5-14], the proliferation of social enterprises in the country is hampered by the lack of legislation regulating their activities and the uncertainty of key concepts and criteria for identifying such enterprises.

To identify all external and internal aspects of the development of social entrepreneurship, it is expedient to conduct a SWOT analysis (Table 1). The implementation of such an analysis will allow identifying the current state and situation of the development of the social entrepreneurship sector in Ukraine. In addition, it will help to 
realize how to counteract threats and reduce risks, as well as how to effectively use the existing capabilities.

According to the SWOT analysis, it becomes clear that the obstacles to the development of social entrepreneurship are the following: the lack of specialized services and support; the impossibility to effectively compete in the field of public procurement; the limited access to investment financial resources; the insufficient qualification of employees, high rents and administrative expenses, etc.

Table 1. SWOT-analysis of the development of social entrepreneurship

\begin{tabular}{|c|c|}
\hline & \\
\hline $\begin{array}{l}\text { Strengths } \\
\text { - participation in continuous economic } \\
\text { activity; } \\
\text { - a clear social goal that benefits society; } \\
\text { - employment of vulnerable groups of the } \\
\text { population; } \\
\text { - ensuring inclusive management and/or } \\
\text { democratic decision-making processes; } \\
\text { - provision of socially meaningful services; } \\
\text { production of socially significant goods; } \\
\text { - high responsibility for the results of their } \\
\text { activities to the population. }\end{array}$ & $\begin{array}{l}\text { - absence of regulatory and legal } \\
\text { support; } \\
\text { - poor awareness of citizens, } \\
\text { enterprises, and organizations about } \\
\text { social entrepreneurship; } \\
\text { - the low motivation for the creation } \\
\text { and operation of social enterprises; } \\
\text { - low level of publicity and imperfect } \\
\text { reporting. }\end{array}$ \\
\hline $\begin{array}{l}\text { Opportunities } \\
\text { - self-organization of social entrepreneurs for } \\
\text { the purpose of exchange of experience; } \\
\text { - influence on the formation of a favorable } \\
\text { legal environment and effective public policy; } \\
\text { - commercial efficiency, self-sustainability, } \\
\text { and competitiveness; } \\
\text { - innovation, innovation in the combination of } \\
\text { social and economic resources; } \\
\text { - founding business schools and conducting } \\
\text { training for social entrepreneurship start-ups. }\end{array}$ & $\begin{array}{l}\text { Threats } \\
\text { - lack of support from state and local } \\
\text { authorities; } \\
\text { - the ineffective policy of informing } \\
\text { the population about social } \\
\text { entrepreneurship; } \\
\text { - low level of personnel qualification } \\
\text { and lack of competent specialists for } \\
\text { the enterprise organization; } \\
\text { - A lack of management mechanisms } \\
\text { that ensure the priority of the social } \\
\text { goal including the interests of various } \\
\text { stakeholders. }\end{array}$ \\
\hline
\end{tabular}

Therefore, the government support provided to social enterprises will ensure a systemic precondition for the development of the social entrepreneurship sector in Ukraine and public-private partnership in providing social services to the population. In addition, officially identifying and legitimizing the functioning of social entrepreneurship will help to define their activities, goals, tasks, etc.

\section{Conclusions}

This research offers some insight into the development of social entrepreneurship in Ukraine having applied modern analytical tools. Conceptual provision for the formation and development of social entrepreneurship has been presented. By means of voluminous analysis, it is possible not only to identify strengths and take into account weaknesses but also to substantiate all existing threats and opportunities for a social enterprise in Ukraine. To summarize, this article opens opportunities for further research using theoretical 
approaches of social entrepreneurship, determinants that can be used at the analysis of the influence of the different factors in the process of providing social entrepreneurship and the results of SWOT analysis to forecast development of the social entrepreneurship in Ukraine.

\section{References}

1. Christine Tamásy (2006) Determinants of regional entrepreneurship dynamics in contemporary Germany: A conceptual and empirical analysis, Regional Studies, 40:4, 365-384, DOI: 10.1080/00343400600612137

2. Schumpeter, J. A. The Theory of Economic Development. Cambridge, MA: Harvard University Press (1934)

3. How Context Shapes Innovation, Journal of Social Entrepreneurship, 5:2, 192213, DOI: $10.1080 / 19420676.2014 .889739$

4. K. Alter, Social enterprise typology (VV LLC, Wilmington, 2007)

5. Elizabeth Chell, Katerina Nicolopoulou \& Mine Karataş-Özkan (2010) Social

entrepreneurship and enterprise: International and innovation perspectives, , 22:6, 485-493, DOI: 10.1080/08985626.2010.488396

6. 3 Z. I. Halushka, Fenomen sots. pidpr-tva: poniat.ta persp. rozv. v Ukr., Visnyk KNU im. T. Shevchenka, 148 (2013)

7. N. M. Horishna, Fenomen sots. pidpr-va: sutn. i kryt., Naukovyi visnyk Uzhh. univ, 2, 39 (2016)

8. Dzh. Kikal, T. Layons, Sots. predpr-vo: missiya - sdelat mir luchshe (Alpina pablisher, Moskva, 2014)

9. M. Naumova, Persp-vy i prob- rozv. sots. pidpr-va v Ukr., Visnyk KNU im. T. Shevch., 8, 185 (2016)

10. D. Bornstein, S. Davis, Social Entrep-ship: What Everyone Needs to Know? (Oxford University Press, 2010)

11. J. Mair, I. Marty Social entrepreneurship research, JWB, 41 (2006)

12. A. Nicholls Playing the field: A new approach to the meaning of social entrepreneurship, SEJ, 2.1 (2006) 